\title{
KREATIVITAS DALAM PEMIKIRAN CSIKSZENTMIHALYI
}

\author{
Aditya Ali \\ Fakultas Komunikasi dan Desain, Universitas Informatika dan Bisnis Indonesia \\ adityaali@unibi.ac.id
}

\begin{abstract}
Abstrak
Kreativitas adalah sebuah istilah yang banyak dihubungkan dengan kemampuan seseorang dalam melahirkan ide-ide baru. Istilah ini pada awalnya lahir dalam dunia psikologi, karena dipandang sebagai bagian dari sifat manusia. Namun dalam perkembangannya, term ini justru banyak digunakan dalam bidang seni dan desain. Frasa-frasa baru seperti seniman kreatif dan desainer kreatif bermunculan sebagai suatu syarat bagi seseorang yang menggeluti bidang tersebut. Sebagai sebuah term yang melekat erat pada bidang seni dan desain, telah berkembang sebuah konsep dari seorang pemikir kreatif yang juga seorang tokoh psikologi humanistik, Csikszentmihalyi. Model dan teori yang dikembangkannya adalah "Social Context of Creativity". Bahwa menurutnya kreativitas adalah suatu sistem yang dibangun dari: person (individu), field (ranah), dan domain (masyarakat). Menurut Csikszentmihalyi ketiga hal tersebut selalu ada, saling melengkapi, saling membangun, dan saling membutuhkan satu sama lain dalam terciptanya suatu kreativitas.
\end{abstract}

Kata kunci: kreativitas, seni dan desain, konteks sosial.

\begin{abstract}
Creativity is a term that has much to do with one's ability to create new ideas. This term was originally born in the world of psychology, because it is seen as part of human nature. But in its development, this term is actually widely used in the field of art and design. New phrases such as creative artists and creative designers emerge as a requirement for someone who wrestles the field. As a term inherent in art and design, a concept of a creative thinker has emerged as a humanistic psychologist, Csikszentmihalyi. The model and theory he developed was "Social Context of Creativity". That he thinks creativity is a system built from: person (individual), field (domain), and domain (community). According to Csikszentmihalyi these three things always exist, complement each other, build each other, and need each other in the creation of a creativity.
\end{abstract}

Keywords: creativity, art and design, social context. 


\section{PENDAhUluan}

Kreativitas dalam perspektif dunia seni dan desain adalah modal awal yang harus dimiliki oleh siapapun yang mengaku dirinya seniman dan desainer. Melahirkan seniman dan desainer yang kreatif lebih berat dari menciptakan suatu karya. Seorang seniman dan desainer kreatif bukan hanya mampu menciptakan karya yang sedap dipandang mata, teringat-ingat dalam pikiran, namun juga karya yang mampu 'berbicara' pada audiensnya. Artinya, seni dan desain yang kreatif adalah karya yang mampu 'berbicara' dalam dua bahasa, yakni bahasa estetika sekaligus bahasa retorika. Audiens bukan hanya menikmati keindahan karya yang dilihatnya, lebih dari itu audiens pun bertambah informasinya, pengetahuannya, bahkan terbujuk, terayu, sampai bertindak mengikuti pesan dalam karya tersebut.

Kreativitas bukanlah sesuatu yang datang begitu saja, bukan karena seorang anak seniman maka otomatis akan mewarisi darah seniman dari bapaknya. Kreativitas juga bukan bakat yang dianugerahkan pada orang tertentu dan tertutup bagi sebagian orang lainnya. Kreativitas diciptakan dan dilahirkan melalui proses belajar dan pengalaman. Kreatitivitas diawali dari minat, yang kemudian dilanjutkan dengan meniru dari yang diamati, mencoba membuat perbaikan dan perbedaan, dan akhirnya berujung pada kemampuan menciptakan hal-hal baru dan diluar kebiasaan. Kreativitas mungkin saja sesuatu yang memang sama sekali baru, belum pernah diciptakan. Atau bisa saja sesuatu yang telah ada sebelumnya namun diperbaiki dan ditambah nilainya sehingga menjadi sesuatu yang baru. Atau kreativitas bisa saja merupakan kombinasi dari hasil-hasil karya dan kreativitas orang lain yang berkembang menjadi hal baru.

Di dunia ini sebenarnya sulit untuk mendeteksi seperti apa karya yang betul-betul baru, karena ketika seseorang berpikir tentang sesuatu ide mungkin saja di belahan dunia yang lain ada orang yang berpikir tentang ide yang sama. Maka dalam hal ini orang yang kreatif adalah orang yang berani mewujudkan ide dan gagasannya lebih dahulu dibandingkan orang lain. Setiap seniman dan desainer pada dasarnya memiliki kemampuan kreativitas pada tingkat yang berbeda-beda, tidak ada orang yang sama sekali tidak memiliki kreativitas. Kreativitas bisa saja berbentuk sebuah ide pemikiran atau sampai bisa diwujudkan dalam bentuk produkproduk kreatif. Kreativitas seseorang merupakan hasil dari proses interaksi antara faktor dari dalam dirinya secara psikologis yakni pemikiran dan perasaan, dan faktor-faktor dari luar dirinya yakni lingkungan (environment).

\section{PEMBAHASAN}

\section{A. Konsep dan Perkembangan Teori}

Konsep tentang kreativitas pada awalnya sangat berkaitan erat dengan dunia psikologi. Namun dalam perkembangannya, istilah ini seringkali didefinisikan secara berbeda-beda. Saat ini banyak sekali definisi yang berkembang tentang istilah ini. Sehingga, pada akhirnya term tentang kreativitas terus dikembangkan definisinya secara luas tergantung dari sudut pandang mana dan digunakan dalam bidang kajian apa.

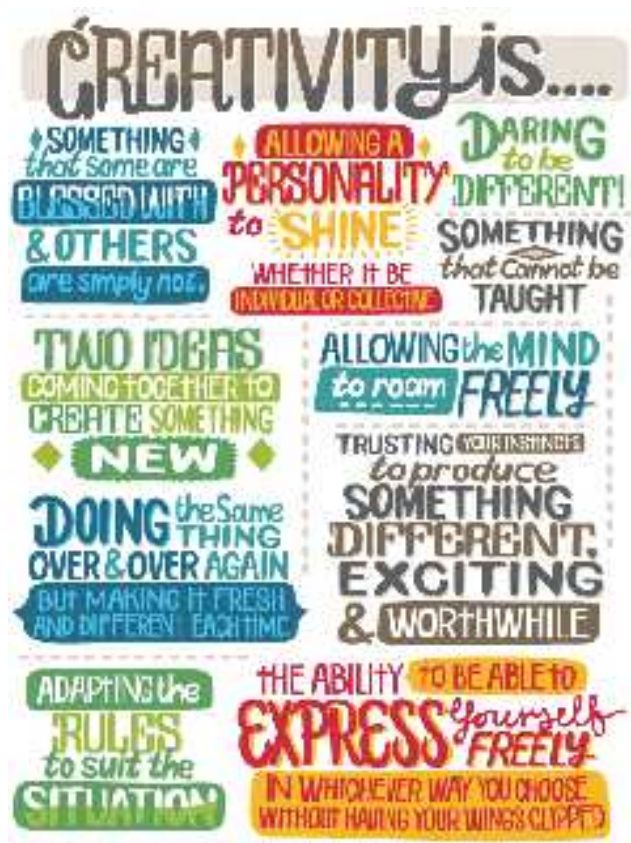

Gambar 2. Grafiti tentang pengertian kreativitas (Sumber: http://kellybrown-a2ms.blogspot.com/2011/06/post-2.html)

Menurut Supriadi (1994) bahwa tidak ada satu definisi pun yang dianggap dapat mewakili pemahaman yang beragam tentang kreativitas. Hal ini disebabkan dua alasan. Pertama, sebagai sesuatu "konstruk hipotesis", kreativitas merupakan ranah psikologi yang kompleks dan multi dimensional,yang mengandung berbagai 
tafsiran.yang beragam. Kedua, definisi kreativitas memberikan tekanan yang berbedabeda, bergantung pada dasar teori yang menjadi acuan pembuat definisi (Sobur, 2003).

Rhodes misalnya (1961, dalam Isaksen, 1987) menganalisis lebih dari 40 definisi tentang kreativitas, menyimpulkan bahwa pada umumnya kreativitas dirumuskan dalam istilah pribadi (person), proses, dan produk. Kreativitas dapat pula ditinjau dari kondisi pribadi dan lingkungan yang mendorong (press) individu ke perilaku kreatif. Rhodes menyebut keempat definisi tentang kreativitas ini sebagai "F our P's of Creativity: Person, Process, Press, Product". Kebanyakan definisi kreativitas berfokus pada salah satu dari empat $\mathrm{P}$ ini atau kombinasinya. Keempat P ini saling berkaitan: Pribadi kreatif yang melibatkan diri dalam proses kreatif, dan dengan dukungan dan dorongan (Press) dari lingkungan, menghasilkan produk kreatif. (Munandar, 2012)

Kerangka pemikiran Rhodes ini setidaknya bisa memberikan gambaran kepada kita tentang bagaimana menemukan definisi kreativitas yang disesuaikan dengan kebutuhan masingmasing disiplin ilmu dan bidang kajian. Torrance (1988) yang memilih definisi proses tentang kreativitas, menjelaskan hubungan antara keempat $\mathrm{P}$ tersebut sebagai berikut: dengan berfokus pada proses kreatif, dapat ditanyakan jenis pribadi yang bagaimanakah akan berhasil dalam proses tersebut, macam lingkungan yang bagaimanakah akan memudahkan proses kreatif, dan produk yang bagaimanakah yang dihasilkan dari proses kreatif? Kerangka pemikiran Rhodes bisa digambarkan dalam diagram di bawah ini.

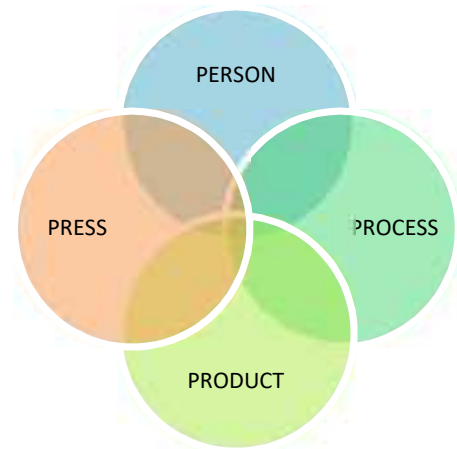

Gambar 2. Rhodes's "F our P's of C reativity: Person, Process, Press Product" )
Definisi kreativitas yang menekankan pada faktor person diantaranya dikemukakan oleh Hullbeck (1945), "Creative action is an imposing of one's own whole personality on the environment in an unique and characteristic way" (Munandar, 2012). Melalui teorinya Hullbeck berpendapat bahwa kreativitas adalah kepribadian dari manusia melalui sesuatu yang unik dan kreatif dalam hidup dan berinteraksi dengan lingkungannya. Pendapat serupa yang sangat mirip dengan definisi Hullbeck datang dari Guilford (1950), "Creativity refers to the abilities that are characteristics of creative people" (Sobur, 2003). Definisi lain yang lebih kompleks lagi tentang bagaimana faktor person menjadi konsentrasi utamanya dikemukakan oleh Sternberg (1998). Dia mengungkapkan bahwa kreativitas merupakan titik pertemuan yang khas antara tiga atribut psikologis: inteligensi, gaya kognitif, dan kepribadian/motivasi. Bersama-sama ketiga segi dari alam pikiran ini membantu memahami apa yang melatarbelakangi individu yang kreatif (Munandar, 2012).

Definisi yang menekankan pada faktor proses yang terkenal dikemukakan oleh Torrance (1988) dimana kreativitas pada dasarnya menyerupai langkah-langkah dalam metode ilmiah, yaitu: ... the process of 1) sensing difficulties, problems, gaps in information, missing elements, something asked; 2) making guesses and formulating hypotheses about these deficiencies; 3) evaluating and testing these guesses and hypotheses; 4) possibly revising and retesting them; and finally 5) communicating the results (Munandar, 2012). Dalam perspektif ini, Torrance merangkai proses-proses dalam mencapai kreativitas, yakni dengan memahami adanya kesulitan, masalah kesenjangan informasi, elemen yang hilang, sesuatu yang menyimpang (a skew), memperkirakan dan merumuskan hipotesis tentang perbedaan-perbedaan, menilai dan mengetes perkiraan (guesses) dan hipotesis, memperbaiki dan mengetes kembali, dan akhirnya mengkomunikasikan hasil.

Dimensi berikutnya dari definisi dan pendekatan terhadap kreativitas menekankan faktor "press" atau dorongan, baik dorongan internal (dari diri sendiri berupa keinginan dan hasrat untuk mencipta atau bersibuk diri secara kreatif) maupun dorongan eksternal dari 
lingkungan sosial dan psikologis. Mengenai "press" dari lingkungan, ada lingkungan yang tidak menghargai imajinasi atau fantasi, dan menekankan kreativitas dan inovasi. Kreativitas juga tidak berkembang dalam kebudayaan yang terlalu menekankan konformitas dan tradisi, dan kurang terbuka terhadap perubahan atau perkembangan baru. Masyarakatlah yang menentukan apa dan siapa yang dapat disebut kreatif. (Munandar, 2012)

Definisi selanjutnya adalah yang berfokus pada produk kreatif dengan menekankan pada orisinalitas, seperti yang dikemukakan oleh Baron (1969) yang menyatakan bahwa kreatifitas adalah kemampuan untuk menghasilkan atau menciptakan sesuatu yang baru. Begitu pula menurut Haefele (1962), kreativitas adalah kemampuan untuk membuat kombinasi-kombinasi baru yang mempunyai makna sosial (Munandar, 2012). Definisi Haefele berbeda dengan definisi Baron yang memandang bahwa orisinalitas pada produk menjadi ukuran dalam menyimpulkan suatu produk yang kreatif. Haefele memiliki pemikiran lain, bahwa suatu produk yang kreatif bisa saja sesuatu yang sudah diciptakan sebelum dan mengalami pengembangan selanjutnya, tidak juga keseluruhan dari suatu produk harus betul-betul baru melaankan bisa dikombinasikan, dan pemikiran Haefele lainnya bahwa suatu produk bisa pula dikatakan kreatif walaupun hanya berubah maknanya.

Sumardjo (2000) menyatakan bahwa di antara beragam karya dan penemuan di berbagai bidang, karya seni seringkali dianggap sebagai puncak pencapaian kreativitas manusia. Kata atau istilah seni (art/kunst) sendiri sebenarnya memiliki beragam pengertian, mulai dari pengertian yang paling umum sampai pada pengertian yang paling sempit atau spesifik; seperti keterampilan (skill), aktivitas manusia, karya (work of art), seni indah (fine art), seni rupa (visual art), dan seni lukis (painting). Menurut Melvin Rader, dalam pengertian karya (work of art) seni adalah perwujudan dari nilainilai seni yang diekspresikan seniman; komunikasi antara seniman dan publik seni melalui karya seni. (Damajanti, 2014)

Istilah tentang kreativitas memang secara tidak langsung banyak bersinggungan dengan dunia seni dan desain. Hal ini masuk akal mengingat kedua bidang ini adalah bidang yang bukan hanya menciptakan sesuatu berdasarkan kemampuan hardskill semata. Lebih jauh dari itu bidang ini menuntut individu-individu yang juga memiliki tingkat kepekaan yang tinggi. Tingkat kepekaan inilah yang kemudian menuntut daya kreatif dari pelakunya. Bagaimana seorang seniman dan desainer mampu melihat sesuatu secara kompleks yang kemudian menentukan arah karya seperti apa yang mesti ia ciptakan. Kreativitas dalam hal ini menjadi solusi yang bisa memcahkan persoalan-persoalan kompleks tadi.

\section{B. Pemikiran Csikszentmihalyi}

Dalam hal seniman sebagai pencipta seni, Csikszentmihalyi (1996), seorang tokoh humanistic psychology sekaligus pendiri Departemen Psikologi, Universitas Chicago, menyatakan bahwa individu yang dianggap kreatif dapat dikelompokkan kedalam tiga kategori, yaitu: (1) Mereka yang mengekspresikan pemikiran-pemikiran tidak biasa (unusual thoughts), (2) Mereka yang mengalami dunia dalam cara-cara yang baru dan orisinal, dan (3) Mereka yang membawa perubahan penting dalam budayanya. Ia menggunakan istilah brilliant untuk kelompok pertama, personally creative untuk kelompok kedua, dan creative unqualifiedly untuk kelompok ketiga. Csikszentmihalyi menjelaskan tipe ketiga sebagai "any act, idea, or product that changes an existing domain, or that transforms an existing domain into a new one," dan individu kreatif sebagai "someone whose thoughts or actions change a domain or establish a new domain". (Damajanti, 2014)

Dalam teorinya, Csikszentmihalyi kemudian mengembangkan sebuah model tentang kreativitas yakni "Social Context of Creativity" ada tiga subsistem yang membangun kreativitas. Pertama, domain yaitu sistem aturan, prosedur, bahasa, simbol, atau pengetahuan yang dimiliki bersama oleh sebuah masyarakat, yang relevan dengan kreativitas. Kedua, ranah (field), yaitu seluruh individu yang secara bersama-sama "menghidupkan" dan "menjaga" domain, agar ide dan gagasan-gagasan baru selalu dapat dihasilkan. Misalnya, ahli seni, kurator, kolektor, kritikus, dan agensi yang 
membangun medan seni. Ketiga, individu (person), yang mampu menghasilkan ide, sistem, prinsip, bentuk atau pola-pola baru. (Piliang, 2010)

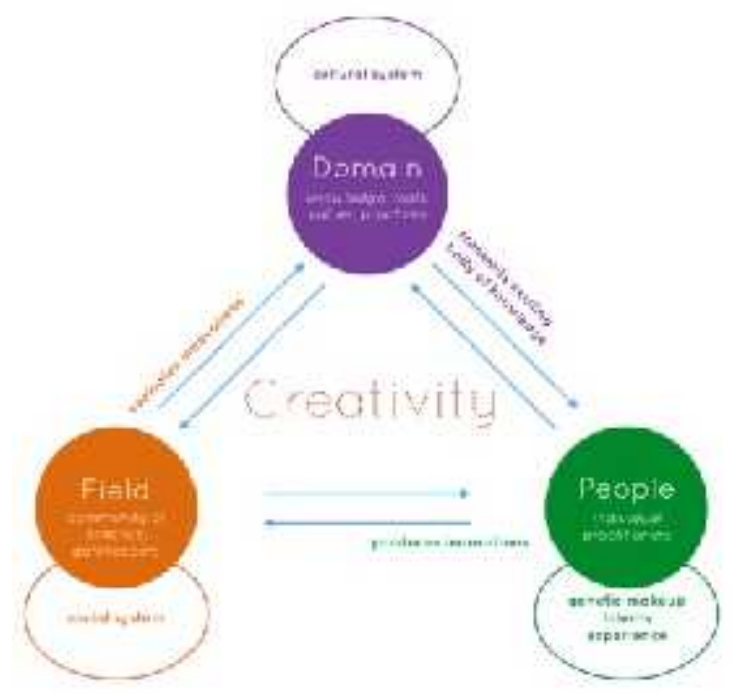

Gambar 2. Social Context of Creativity Model (Sumber: http://www.dynacd.com/main-body/)

Konsep tentang kreativitas yang ditawarkan Csikszentmihalyi berangkat dari cara berpikir yang komprehensif bahwa kreativitas bukanlah sesuatu yang ada begitu saja. Atau kreativitas bukanlah sesuatu yang berkembang tanpa berkaitan dengan sub-sub sistem lainnya yang membangun kreativitas itu sendiri. Memang pada kenyataannya kreativitas tidak akan terbukti secara formal kecuali ditampilkan dalam suatu karya yang disebut kreatif. Namun bisa saja karya kreatif tersebut merupakan buah tangan pihak lain, dalam hal ini bisa saja seorang seniman atau desainer hanya berperan pada tingkat ide maupun gagasannya.

Sawyer (2006) menyatakan bahwa Individu, dalam hal ini seniman, adalah sumber dari inovasi; ia mengawali proses dengan mengembangkan karya ciptaan. Namun ini saja belum bisa disebut kreatif, karena karya tersebut mungkin tidak baru, dan mungkin juga tidak layak. Bagaimana kita dapat menilai kebaruan dan kelayakan sebuah karya? Dalam hal ini peneliti tidak seharusnya memutuskannya sendiri; mereka seharusnya berpaling pada kesepakatan orang-orang yang dianggap akhli dalam bidang kreatif tersebut: lapangan (field). Lapangan menentukan apakah karya tersebut baru dan layak. Jika lapangan memutuskan bahwa karya tersebut memenuhi kriteria, maka karya memasuki bidang (domain), dimana ia dijaga dan disebarkan kepada anggota lapangan yang lain. (Damajanti, 2014)

Seseorang tidak bisa kreatif dalam sebuah domain dimana ia tidak diekspos. Tidak peduli betapa hebat pun bakat seni yang dimiliki seseorang, ia tidak akan dapat berkontribusi pada bidang seni rupa tanpa mempelajari hukum-hukumnya. Namun meskipun hukumhukumnya dipelajari, kreativitas tidak dapat dimanifestasikan tanpa kehadiran sebuah field yang mengenali dan melegitimasi sumbangan barunya. Seseorang bisa saja belajar seni rupa melalui caranya sendiri dengan menemukan buku yang tepat dan mentor yang tepat, namun tidak akan dapat membuat perbedaan dalam domain tanpa pengakuan dari medan sosial seni rupa yang akan menjadi saksi untuk kelayakan kontribusinya. (Damajanti, 2014)

Menurut Piliang (2010), kreativitas harus dipahami secara lebih komprehensif, dengan mengurai "ranah" (field) lebih luas di mana ia tumbuh, beserta "modal" (capital) yang diperlukan di dalamnya. "Ranah" adalah sebuah struktur dinamis yang di dalamnya ada pertarungan ide-ide dan posisinya dalam masyarakat, dengan melibatkan sumber daya dan "modal" berbeda-beda. Struktur "ranah" akan menentukan apakah sebuah ide dan gagasan kreatif dapat bersaing dan diterima di dalam masyarakat. Dalam konteks karya seni, "ranah seni" (artistic field) adalah sebuah ruang perebutan posisi "kebaruan" atau "orisinalitas" artistik, yang dibangun melalui kepemilikan berbagai modal yang diperlukan dalam menghasilkannya. Dengan mempertimbangkan "ranah" dan "modal" tersebut di atas, kita dapat mengusulkan sebuah "ranah" khusus kreativitas, yang disebut "ranah kreatif" (creative field). "Ranah kreatif" adalah "sebuah ruang pertarungan kreativitas terstruktur untuk menghasilkan kebaruan dan ide orisinil, yang ditentukan oleh modal kreatif yang dimiliki. Kita dapat mengidentifikasi empat ranah yang mengkonstruksi sebuah lingkungan kreatif: "ranah ekspresi" (field of expression) sebagai sebuah medan yang di 
dalamnya ide-ide baru atau inovasi dihasilkan; "ranah produksi" (field of production) sebagai sebuah medan yang didalamnya ide-ide baru direalisasikan melalui berbagai "cara produksi" (yang tidak hanya "produksi ekonomi", tetapi juga "produksi sosial", "produksi kultural"); "ranah diseminasi" (field of dissemination) sebagai sebuah medan yang di dalamnya "produk-produk kreatif" didiseminasikan; dan "ranah apresiasi" (field of appreciation) sebagai sebuah medan "wacana" (discourse), yang di dalamnya karya-karya kreatif diapresiasi dan diberikan nilai melalui standard penilaian tertentu. (Piliang, 2010)

Selebihnya bahwa domain dan field adalah variabel yang selalu ada atau merupakan variabel tetap. Yang menjadi permasalahannya sekarang adalah bahwa suatu kreativitas tidak akan terwujud tanpa adanya variable tidak tetapnya yakni individu (person), yang dalam hal ini diwakili oleh seniman dan desainer. Merekalah yang kemudian menjadi ujung tombak sebuah karya kreatif, bahwa sebuah karya sekecil ataupun sebesar apapun hebatnya pasti aakan diwakili oleh nama tertentu sebagai penciptanya. Seniman dan desainer adalah person yang selalu harus dilahirkan sebagai "the subject of creativity". Bahkan yang menciptakan field dari kreativitas bisa saja adalah para seniman dan desainer itu sendiri.

Dalam hal ini Csikszentmihalyi (Houqe, 13) mengemukakan sepuluh pasang ciri-ciri kepribadian kreatif yang seakan-akan paradoksal tetapi saling terpadu secara dialektis:

1. Pribadi kreatif mempunyai kekuatan energi fisik yang memungkinkan mereka dapat bekerja berjam-jam dengan konsentrasi penuh, tetapi mereka juga bisa tenang dan rileks, tergantung situasinya.

2. Pribadi kreatif cerdas dan cerdik tetapi pada saat yang sama mereka juga naiff. Mereka nampak memilliki kebijaksanaan (wisdom) tetapi kelihatan seperti anak-anak (child like). Insight mendalam nampak bersamaan dalam ketidakmatangan emosional dan mental. Mampu berfikir konvergen sekaligus divergen.

3. Ciri paradoksal ketiga berkaitan dengan kombinasi sikap bermain dan disiplin.

4. Pribadi kreatif dapat berselang-seling antara imajinasi dan fantasi, namun tetap bertumpu pada realitas.
5. Keduanya diperlukan untuk dapat melepaskan diri dari kekinian tanpa kehilangan sentuhan masa lalu.

6. Pribadi kreatif menunjukkan kecenderungan baik introversi maupun ekstroversi.

7. Orang kreatif dapat bersikap rendah diri dan bangga akan karyanya pada saat yang sama

8. Pribadi kreatif menunjukkan kecenderungan androgini psikologis, yaitu mereka dapat melepaskan diri dari stereotip gender (maskulin-feminin)

9. Orang kreatif cenderung mandiri bahkan suka menentang (passionate) bila menyangkut karya mereka, tetapi juga sangat obyektif dalam penilaian karya mereka.

10.Sikap keterbukaan dan sensitivitas orang kreatif sering menderita, jika mendapat banyak kritik dan serangan, tetapi pada saat yang sama ia merasa gembira yang luar biasa.

\section{PENUTUP}

Wacana tentang kreativitas selalu dihubungkan dengan kemampuan-kemampuan dalam melahirkan ide-ide dan gagasan baru. Ide dan gagasan ini sebenarnya tidak harus sama sekali baru. Yang paling penting dalam pemikiran Csikszentmihalyi bahwa kreativitas adalah rangkaian dari sebuah system kreatif yang terdiri dari person, domain, dan field. Ketiganya bersatu pada dalam membentuk apa yang kemudian kita sebut kreativitas.

Seniman dan desainer adalah person yang harus selalu ada dan diciptakan agar term kreativitas tidak hilang. Merekalah --dalam ranah ini-- individu-individu yang diharapkan mampu dan selalu melahirkan ide-ide dan gagasan segar yang tidsk harus selalu baru. Dilain pihak kreativias person tidak akan tereksplorasi dengan baik apabila tidak melihat peluang pada field. Bahwa kreativitas memiliki ruang-ruang tersendiri sebagai media apresiasi bagi person. Namun person dan field pun tidak akan bekerja dengan semestinya bila tidak ada domain yang memberikan apresiasi atas pdroduk karya sekreatif apapun yang telah diciptakan.

Kuncinya adalah bagaimana para seniman dan desainer mampu mengkolaborasikan person, domain, dan field dalam menghasilkan 
karya-karya yang kreatif. Masyarakat pada dasarnya senantiasa menunggu kehadiran para seniman dan desainer yang dengan daya kreativitasnya --setidaknya-- mampu memecahkan masalah-masalah mereka walaupun kecil tapi bermakna. Pada akhirnya, pesan untuk para seniman dan desainer, "Jangan pernah bosan menjadi orang kreatif, sekecil apapun ide dan karya kita, itulah ide dan karya terbaik dari sebuah kreativitas".

\section{REFERENSI}

Damajanti, I. (2014, February 13). http://salihara.org/media/documents/2014/ 02/13/k/a/kajian_aspek_kreativitas_dalam _pameran_karya_trimatra_di_antara.

Retrieved May 15, 2014, from http://salihara.org
Houqe, F. (13, April 9). https://www.fastcompany.com/3016689/10 -paradoxical-traits-of-creative-people.

Retrieved January 11, 2018, from www.fastcompany.com.

Munandar, U. (2012). Pengembangan Kreativitas Anak Berbakat. Jakarta : PT. Rineka Cipta.

Piliang, Y. A. (2010, July 29). http://www.isidps.ac.id/berita/pendidikan-tinggi-senidalam-dinamika-industri-kreatif-danperannya-dalam-membangun-karakterbangsa. Retrieved May 15, 2014, from http://www.isi-dps.ac.id: http://www.isidps.ac.id

Sobur, A. (2003). Psikologi Umum. Bandung: CV. Pustaka Setia. 